This PDF is a selection from an out-of-print volume from the National Bureau of Economic Research

Volume Title: Tax Policy and the Economy, Volume 11

Volume Author/Editor: James M. Poterba, editor

Volume Publisher: MIT

Volume ISBN: 0-262-16167-2

Volume URL: http://www.nber.org/books/pote97-1

Conference Date: October 22, 1996

Publication Date: January 1997

Chapter Title: Distributional Effects of Adopting a National Retail Sales Tax

Chapter Author: Daniel R. Feenberg, Andrew W. Mitrusi, James M. Poterba

Chapter URL: http://www.nber.org/chapters/c10905

Chapter pages in book: (p. 49 - 90) 


\title{
DISTRIBUTIONAL EFFECTS OF ADOPTING A NATIONAL RETAIL SALES TAX
}

\author{
Daniel R. Feenberg \\ NBER
}

\author{
Andrew W. Mitrusi \\ NBER
}

James M. Poterba

MIT and NBER

\section{EXECUTIVE SUMMARY}

This paper describes a new household-level data file based on merged information from the IRS Individual Tax File, the Current Population Survey, the National Medical Expenditure Survey, and the Consumer Expenditure Survey. This new file includes descriptive data on household income as well as consumption. The data file can be linked to the NBER TAXSIM program and used to evaluate the distributional effects

We are grateful to Thomas Barthold, David Burton, Laura Dale, Martin Feldstein, Don Fullerton, Jane Gravelle, Laurence Kotlikoff, Gilbert Metcalf, Thomas Woodward, and especially John Sabelhaus for helpful discussions, to John Sabelhaus for providing us with an edited copy of the 1990-1992 Consumer Expenditure Survey family-level data file, and to the National Science Foundation (Poterba), NBER, and Americans for Fair Taxation for research support.

Daniel R. Feenberg is a Research Associate at the National Bureau of Economic Research. Andrew W. Mitrusi is an Economist at the National Bureau of Economic Research. James M. Poterba is the Mitsui Professor of Economics at the Massachusetts Institute of Technology and the Director of the Public Economics Research Program at the National Bureau of Economic Research. 
of changing the federal income tax code, as well as the distributional effects of replacing the individual income tax with a consumption tax. We use this data file to analyze the long-run distributional effects of adopting a national retail sales tax that raises enough revenue to replace the current federal individual income tax and corporation income tax, as well as federal estate and gift taxes. Our results highlight the sensitivity of the change in distributional burdens to provisions such as lump sum transfers, sometimes called "demogrants," in the retail sales tax plan, and to the choice between income and consumption as a basis for categorizing households in distribution tables.

\section{INTRODUCTION}

The "flat tax" debate has drawn new attention to the distribution of tax burdens under the current income tax system compared to that under alternative tax regimes. Unlike calculations of the differential burdens of alternative income tax plans, which can be based largely on data for current income tax filers, complete analysis of the steady state distribution of tax burdens under consumption-based tax systems requires information not just on income flows, but also on consumption outlays for a sample of households. No single data set includes all of this information, so any distributional analysis requires combining information from different public use data files.

Samples of tax returns such as the Statistics of Income Individual Tax File are the standard source of information on taxable income, but tax returns do not include any direct information on the level or pattern of household consumption spending. The data bases that provide detailed information on consumption spending, such as the Consumer Expenditure Survey (CES), do not have any detailed information on many elements of taxable income, and they provide only sketchy information regarding the high-income households that are often the focus of discussion in tax reform debates. The absence of information on passive losses, capital gain realizations, and many other factors makes it particularly difficult to estimate the income tax liabilities of high-income households using data files such as the CES. The Panel Survey of Income Dynamics, a standard data source on household incomes that has been used in a number of academic studies of how income affects consumption spending, contains information on only a small number of consumption variables, such as food, utilities, and rent, that together account for a limited fraction of household budgets.

Many of the previous attempts to compare the distribution of tax bur- 
dens under income and consumption taxes are incomplete. Others have been conducted by various government agencies, and full details on the procedures used to link consumption and income have not been released to the research community. Nunns (1995) notes that the Office of Tax Analysis employs a merged data base of the type developed here; Kasten and Toder (1995) describe a similar data base at the Congressional Budget Office, and Barthold and Jack (1995) allude to similar data developed by the Joint Committee on Taxation. Many household-level comparisons between the current income tax and potential consumption tax options fail to consider the distribution of corporate income tax payments, and their allocation across households, even though such imputed payments can represent a sizable fraction of the income tax burden, especially for high-income households. A related difficulty is the failure to consider the estate tax. Many proposals to reform the income tax system are packaged with proposals to eliminate the estate tax, and it is therefore important to develop an estimate of the distribution of estate tax burdens.

Another common difficulty with tax plan comparisons is the absence of information on individuals who do not currently file income tax returns. It is particularly important to identify these nonfilers when analyzing the distributional effects of consumption taxes administered at the retail level, since individuals who are currently outside the income tax system will face retail sales tax liability.

In this paper, we develop a new data base with information on household-level income, consumption spending, and tax liability. We extend the IRS Individual Income Tax File, the data file that is the basis for distributional analysis of income tax reforms using the NBER TAXSIM program, in four directions. First, we include nonfilers in the analysis. We identify households in the Current Population Survey that are designated as nonfilers, and we add the data records for these households to the Individual Income Tax File. Second, we include an estimate of corporate income taxes, and estate and gift taxes, paid on behalf of all potential taxfiling units in our analysis. Third, we impute to each potential tax filing unit in our expanded data base total and disaggregate consumption spending using information from the Consumer Expenditure Survey. Finally, because the CES only includes information on out-of-pocket medical expenditures, we impute consumption of medical services using data from the National Medical Expenditure Survey.

The resulting data base, while it cannot answer some of the questions that can be addressed with a household-level survey with information on income and consumption, provides us with the capacity to analyze the distributional effects of a range of tax reform proposals. In the cur- 
rent paper we focus on proposals for a retail sales tax. Our analysis focuses on the long-run effects of replacing the current income tax, or the income tax and payroll tax, with a retail sales tax. We develop distribution tables based on household consumption spending, and a proxy for lifetime income, as well as a "snapshot" annual income measure, and compute the distribution of tax burdens under various tax reform plans. We do not consider the transitional incidence effects that would be associated with changes in the real value of assets at the time of tax reform. Analyzing these transitional effects would require merging additional data on asset holdings to data on income and consumption outlays.

The current paper is divided into five sections. The first summarizes the retail sales tax and presents calculations, based on aggregate data from the National Income and Product Accounts, of the tax rate at which the retail sales tax could raise the same amount of revenue as the current income, or income and payroll, tax system. Section two describes the details of our data linkage algorithm. It summarizes the procedures that we use to merge nonfilers into the Tax File, to impute consumption and medical spending to our data records for tax filers and nonfilers, and to impute corporate and estate and gift tax liability to tax filers and nonfilers. The third section presents the results of our comparative distributional analysis of the current income and payroll tax system and a potential retail sales tax system. Section four discusses a number of transitional issues that arise with regard to the retail sales tax. The final section summarizes our findings and discusses other potential applications of the framework developed in this paper.

\section{ESTIMATING THE RETAIL SALES TAX RATE: AGGREGATE CALCULATIONS}

This section considers the definition of the retail sales tax base, and presents simple calculations of the retail sales tax rate that would raise the same amount of revenue as the current federal income tax system, or the income tax and payroll tax systems. We present such estimates using National Income and Product Account (NIPA) data for calendar year 1991 as published in the January/February 1996 issue of the Survey of Current Business, because our subsequent distributional analysis relies on data from 1991.

Table 1 shows the 1991 revenues associated with the federal income tax as well as the payroll tax. The entry for corporate income tax revenues excludes contributions to the federal treasury from Federal Reserve banks ( $\$ 20.8$ billion), since such tax payments would continue under a National Retail Sales Tax (NRST). Total 1991 tax payments under the 
TABLE 1

Federal Income and Payroll Taxes, 1991 (\$billions)

Personal income tax

$\$ 464.4$

Estate \& gift taxes

11.0

Corporate profits taxes

89.0

Total income taxes

564.4

Employer payroll tax

177.5

Employee payroll tax

177.9

Self-Employed payroll tax

21.2

Total payroll taxes

376.6

Total income \& payroll taxes

941.0

Source: National Income and Product Accounts, Survey of Current Business January/February 1996.

income tax system, including personal income taxes, estate and gift taxes, and the corporate income tax, were $\$ 564.4$ billion. ${ }^{1}$ Including federal OASDI and Medicare taxes raises the revenue total by another $\$ 376.6$ billion, to $\$ 941$ billion.

The retail sales tax base can be estimated using the National Income Accounts concept of personal consumption expenditures (PCE) from NIPA Table 2.4 as a starting point. Total personal consumption expenditures equalled $\$ 3,975.1$ billion in 1991 . There are several reasons, however, why the sales tax base would differ from the PCE aggregate. The most important adjustments to this consumption flow are described below. ${ }^{2}$

\subsection{Adjusting PCE for Indirect Taxes}

Personal consumption expenditures in the NIPA include outlays for indirect taxes, such as state sales taxes and federal excise taxes. Such tax payments would not be part of the retail sales tax base, and it is therefore

1 The National Income and Product Accounts report income tax liabilities on a payments basis. The entry for 1991, for example, shows all individual income taxes paid during calendar year 1991. The individual income tax returns in the Tax File that we use in later sections report tax liability. A household's 1991 tax liability may include some tax that was paid in 1992. Aggregate tax liability and tax payments can differ for a given year; Park (1994) reports that for 1991, this difference is roughly $\$ 16$ billion. We use the payment measure in our aggregate analysis of the retail sales tax, and rescale the liability data on individual tax returns to match this aggregate in our analysis below.

2 Bartlett (1995) and Burton and Mastromarco (1996) discuss a number of issues associated with the retail sales tax base and the administration of the tax. 
necessary to subtract these taxes from the consumption aggregate. NIPA Table 3.5 disaggregates receipts from state and local sales taxes and federal excise taxes by category. The taxes that are paid at the retail level include state and local general sales taxes ( $\$ 127.8$ billion), specialized state and local excise taxes on gasoline, alcoholic beverages, tobacco, and public utilities ( $\$ 43.5$ billion total), and specialized federal excise taxes on gasoline, alcoholic beverages, tobacco, and air transport ( $\$ 32.3$ billion). The unspecified category of "other" federal, state, and local excise taxes ( $\$ 20.5$ billion) is also assumed to be paid at the retail level; this adjustment will tend to understate the retail sales tax base. The total adjustment to PCE for these indirect taxes is $\$ 224.1$ billion. This amount must be subtracted from personal consumption expenditures in defining the retail sales tax base. ${ }^{3}$

\subsection{Owner-Occupied Housing in the Retail Sales Tax Base}

One difficulty in defining the retail sales tax base arises with respect to owner-occupied housing. The equivalent "rental income" from such housing is imputed in the National Income and Product Accounts. It is not observed in a market transaction. Because taxing such imputed rent requires estimating its value on a household-by-household basis, and could involve substantial administrative burdens that would not otherwise be necessary under a retail sales tax, we follow the "prepayment method" of taxation and exclude imputed rent from the retail sales tax base, while including the value of new owner-occupied homes at their time of purchase. ${ }^{4}$

To adjust PCE to recognize this prepayment treatment of owneroccupied housing, we need to subtract imputed rent from PCE, and to add to it the value of owner-occupied housing purchases. In 1991, the NIPA imputation for space rent on owner-occupied nonfarm housing (Table 2.4) was $\$ 434.1$ billion. The analogous imputation for farm housing, which we assume to be owner-occupied, was $\$ 5.2$ billion. NIPA Table 5.6 reports purchases of new single-family permanent site structures of $\$ 95.4$ billion, purchases of mobile homes of $\$ 4.3$ billion, and total improvements to residential property of $\$ 47.2$ billion..$^{5}$ We assume that

${ }^{3}$ Unlike state and local sales taxes, property taxes on owner-occupied housing are not included in NIPA personal consumption expenditures. They are tabulated in personal tax and nontax payments, and therefore do not need to be subtracted from PCE in arriving at the retail sales tax base.

4 Graetz (1980) demonstrates the equivalence of the prepayment method and other ways of taxing the service flow from durable goods.

5 The ratio of new home sales to imputed rent may be sensitive to macroeconomic fluctuations that affect the level of new construction, so the relationship between these two measures of the tax base would in practice differ depending on the particular year chosen for the analysis. 
all purchases of single-family homes represent purchases of owneroccupied homes for this part of our calculation.

Improvements to existing structures would also be taxed under the prepayment analysis. We allocate improvements between single-family homes and multifamily structures in proportion to their shares of new permanent-site investment. New multifamily residential investment was $\$ 15.1$ billion in 1991 . This implies that $95.4 /(15.1+95.4)$, or 0.863 , times the value of total improvements can be considered as additions to the stock of owner-occupied real estate, which implies estimated improvements to single-family structures of $\$ 40.8(0.863 \times 47.2)$ billion.

The net effect of these adjustments, which render the retail sales tax base substantially smaller than PCE, is shown below.

Purchases of new single-family homes

Purchases of new mobile homes

Improvements to single-family homes

Space rent on owner-occupied housing

Space rent on farm housing

Total adjustment for owner-occupied housing
$\$ 95.4$ billion

4.3

40.8

(298.8) billion

\subsection{Other Adjustments}

NIPA imputes the difference between income and outlays of banks, credit agencies, and investment companies to the household sector as implicit services of financial intermediaries. This component of personal consumption expenditures would not be taxed under some versions of a retail sales tax. This imputed interest flow equals $\$ 133.2$ billion for 1991 (NIPA Table 8.18); we subtract this amount from PCE in estimating the retail sales tax base.

In addition, several additional sub-categories of consumption are likely to be excluded from the retail sales tax base because they are difficult to measure or administratively difficult to tax. These include foreign travel ( $\$ 39.7$ billion), spending by U.S. residents in other nations ( $\$ 3.8$ billion), and food produced and consumed on farms ( 0.6 billion). ${ }^{6}$

We do not explicitly consider potential compliance difficulties with the retail sales tax. This issue arises both with respect to current underground economy transactions, which are not reported and are therefore not part of the income tax or the retail sales tax base, as well as transactions that might be hidden from the tax authority under the retail sales

6 The Treasury Department's (1984) discussion of value-added taxation also excluded several other categories of consumption, such as outlays on education, religious and welfare groups, local mass transit, and domestic services, as administratively or politically difficult to tax. We have not excluded these items from our retail sales tax base. 
TABLE 2

Adjustments to Personal Consumption Expenditures to Estimate the Retail Sales Tax Base

NIPA personal consumption spending

$\$ 3,975.1$ billion

Adjustment for indirect taxes

Adjustment for owner-occupied housing

Adjustment for imputed financial services

Adjustment for "difficult to tax" items

Retail sales tax base

$\$ 3,274.9$ billion

Source: Authors' calculations based on data from the National Income and Product Accounts as reported in the January/February 1996 Survey of Current Business. See text for further description.

tax but not under the current system. The PCE aggregate does include an estimate of otherwise-unreported consumption spending.

\subsection{Implications for the Retail Sales Tax Rate}

Table 2 summarizes the net effect of the various adjustments to personal consumption expenditures that are described above. The NRST rate equals required revenue, $\$ 564.4$ billion in the case of the income tax and $\$ 941$ billion for the income and payroll taxes, divided by the tax base $(\$ 3,274.9)$. This translates into a retail sales tax rate of 17.2 percent to replace the income tax, and 28.7 percent to replace both the income and payroll taxes. ${ }^{7}$ This calculation applies to a retail sales tax without any exclusions from the tax base or any lump-sum transfers designed to alter the distributional characteristics of the tax burden. In the detailed calculations we present below, we consider the effect of such exclusions and modifications on the pattern of distributional burdens.

Some retail sales tax proposals call for taxing some or all government purchases. If the federal government adopted a policy of collecting sales tax on all of its own purchases, such a tax would collect precisely the same amount in revenue that it would cost the federal government, and it would have no effect. This assumes that federal spending in nominal dollars could rise to reflect the higher tax-inclusive price of federal purchases. If tax-inclusive spending was fixed at its pre-retail sales tax level, then taxing federal purchases would shrink the real value of federal spending. This would not represent a standard experiment in tax inci-

7 These tax rates are presented in the same manner as current state retail sales taxes: the tax rate is a percentage of the producer price. It would also be possible to report tax rates as a fraction of the total consumer price, $t /(1+t)$; these rates would be lower but would correspond to the same revenue potential. 
dence analysis, since it would change both the set of goods purchased by the government and the tax system.

Including state and local government purchases in the retail sales tax base would have different effects, since the revenue collected by the federal government would not necessarily be transferred to states and localities to offset the higher cost of their purchases. One particular proposal, which illustrates the approach, would apply the retail sales tax to all government spending other than employee compensation. In 1991, state and local governments spent $\$ 265.5$ on non-payroll items. If this spending were added to the retail sales tax base, the required retail sales tax rate would fall to 15.9 percent for the income tax replacement, and to 26.6 percent for the income and payroll tax replacement.

Federal revenue in this case is generated by taxing state and local government purchases, and a complete incidence analysis would need to specify the distribution of gains and losses from reduced real expenditures by states and localities. Because such an analysis requires strong and ad hoc assumptions about the benefit distribution, we do not consider such proposals in our analysis below.

\section{THE EXPANDED TAX FILE DATA BASE}

Our empirical work is directed toward generating a new data file with information on income, individual income tax payments, imputed corporate, estate, and gift taxes, and estimates of consumption expenditures for each household. To create this file, we combined data from Statistics of Income Public Use Individual Tax File (the Tax File) with data from the Current Population Survey (CPS), the National Medical Expenditure Survey (NMES), and the Consumer Expenditure Survey (CES).

Our development of this data base proceeded in six steps, which are detailed below. First, we used CPS data to add information on nonfiling households to the Tax File. Second, we imputed consumption expenditures to all households in the Tax File-CPS file by developing a synthetic match with the Consumer Expenditure Survey. Third, we augmented the CES-based information on consumption with additional data on medical expenditures from the NMES. Fourth, we imputed corporate income tax payments to households in the Tax File-CPS data file. Fifth, we imputed estate and gift tax liability to the households in our resulting data base. Finally, we used data from the Current Population Survey to allocate labor income within households between men and women, so that we could calculate payroll tax liabilities. This section describes the procedures that we followed in each step of this process. 


\subsection{Augmenting the Tax File to Include Non-Filers}

One difficulty with distributional analyses based solely on the Tax File is that this data file is based on tax return filings and as such excludes households that do not file tax returns. In 1991, single individuals with adjusted gross income below $\$ 5,500$, and married couples with income below $\$ 10,000$ were not required to file tax returns. In addition, many households have income that is not subject to tax, such as interest on municipal bonds, so that their household income exceeds the cutoffs even though they are not tax filers. Because such households would incur tax liability under a retail sales tax, it is important to include them in any distributional analysis.

Our long-range intention is to obtain a sample of actual nonfilers from the Survey of Income and Program Participation (SIPP), and to merge these nonfilers with the data records in the Tax File. However, initial work with SIPP 1990 Wave 5 showed an implausible amount of wage and other income for self-declared nonfiling couples. We therefore followed an alternative strategy. Recently, the Current Population Survey (CPS) has imputed tax filing status for all adult respondents. Although the CPS imputation is based on income and probable withholding, the Census has access to an exact match file linking the CPS with IRS master files of tax returns. The CPS imputation of tax filing status is therefore likely to be much more accurate than any imputation that we might carry out.

We use the CPS imputation of filing status to identify a subsample of CPS respondents who are nonfilers. From the March 1992 CPS, we have extracted individuals over 18 years of age and married couples with an imputed status of "nonfiler" and added them to the Tax File. Younger persons living with nonfilers are counted as dependents. Income information for 1991, including benefits received from social welfare programs, is taken from the CPS without change, and the CPS March Supplemental Weight is used for scaling to U.S. population totals.

This procedure yields 13.3 million households that were nonfilers according to the CPS imputation algorithm. Of this group, 8.8 million are one-person households and another 2.6 million are two-person households. Table 3 presents summary information on the distribution of filers and nonfilers by income category. The income variable is defined based on the Form 1040 concept of gross income, and also includes transfer income for households that are drawn from the CPS data base.

The first column of Table 3, which reports the number of potential tax filers, shows the total number of households in each income range that we identified based on both the Tax File and the CPS nonfiler data base. The second column reports the fraction of households in each income 
TABLE 3

Distribution of Filers and Non-filers by Income Class

\begin{tabular}{lcc}
\hline Household income & $\begin{array}{c}\text { Total number (millions) } \\
\text { of tax filing units }\end{array}$ & $\begin{array}{c}\text { Fraction of tax } \\
\text { filing units that file }\end{array}$ \\
\hline Less than zero & 0.6 & 0.856 \\
$0-5,000$ & 15.3 & 0.553 \\
$5-10,000$ & 17.6 & 0.716 \\
$10-15,000$ & 13.9 & 0.925 \\
$15-20,000$ & 12.1 & 0.978 \\
$20-30,000$ & 18.2 & 0.995 \\
$30-40,000$ & 13.1 & 0.998 \\
$40-50,000$ & 9.3 & 0.999 \\
Greater than 50,000 & 18.1 & 1.000 \\
\hline
\end{tabular}

Source: Authors' calculations based on Tax File-CPS data file. The income concept used to allocate households to classes includes all cash income items but does not include the imputed value of owner occupied housing in excess of cash outlays on housing or medical expenses that are not out of pocket. The income concept used in Tables 5-12 does include these imputations.

category who actually file tax returns. Not surprisingly, the nonfilers are heavily concentrated in cells with low household income. Just over half of the nonfilers are estimated to have household incomes of less than $\$ 5,000$. The finding that more than one-third of households with incomes below $\$ 10,000$ are identified as nonfilers underscores the importance of adding nonfilers to the tax return data base before performing distributional analyses. ${ }^{8}$

\subsection{Matching the Tax File/CPS Sample to the Consumer Expenditure Survey}

After augmenting the Tax File with the CPS sample of nonfilers, we imputed consumption expenditures to all of the households in this expanded data base. ${ }^{9}$ We did this with a random matching algorithm that links each Tax File or CPS record to a "similar" record in the 1991 Consumer Expenditure Survey. The critical step in this process was defining "similar." We sorted households on several dimensions: the total value of gross income including welfare benefits ${ }^{10}$, the number of persons in

${ }^{\beta}$ In constructing distribution tables, we exclude households with negative reported incomes. These are primarily households with large reported losses on their tax returns. This does not substantially affect our findings and preserves comparability between our various methods of computing distribution tables.

9 Okner (1974) and subsequent symposium papers discuss potential pitfalls that may arise in merging information from one data set to data from a second data set.

10 We define this income concept as the sum of wages, business income, farm and rental income, dividends, interest, pensions, Social Security income, SSI, unemployment, workers compensation, welfare, and the value of Food Stamps. 
the household, whether or not there is anyone in the household over the age of 65 , and whether the household has capital income in excess of $\$ 2,500$ per year. Each of these variables was chosen because it can be measured in both the Tax File-CPS data file and in the Consumer Expenditure Survey. These characteristics therefore provide a basis for linking households in the two files. ${ }^{11}$

The Consumer Expenditure Survey data that we analyzed are from an edited version of the 1990 through 1992 CES Family-Level data files; this data base and its relation to aggregate consumption measures are described in Sabelhaus (1996). We assigned CES households to cells based on the four characteristics noted above. In some cases, for example, for households with one or two members near the middle of the income distribution, there were several hundred observations in a cell. In other cells, however, particularly high income cells and cells with elderly individuals and more than two members in the household, there were relatively few CES households. To ensure a reasonable sample for our random matching algorithm, we imposed the rule that when a cell had fewer than ten members, it was combined with another cell containing households that were similar along at least two, but often three, of the four classifying dimensions. Table 4 shows the resulting number of CES households in each of the various cells that we used to impute consumption outlays to the Tax File-CPS data file. It also shows the set of household grouping along income and demographic dimensions that we used in our analysis.

Our algorithm for imputing consumption outlays to Tax File-CPS households proceeded as follows. Each record in the combined Tax FileCPS data file was assigned to the appropriate income/demographic cell, using our CES-based categories to define these cells. We then selected, by random draw recognizing the different sample weights for different households, one of the CES households in this cell. We calculated the ratio of total consumption expenditure to household income, as well as the ratios of several sub-categories of consumption to household income, for this household, and we then multiplied these ratios by the household income of the household in the Tax File-CPS data file to estimate its consumption spending. We used ratios of consumption to income to carry out our imputation because this procedure reduced the incidence of extreme consumption values at low and high income levels. Even with this procedure, however, some of the consumption imputations appear ex-

11 We selected a capital income threshold of $\$ 2,500$ per year based on simple regression analysis of consumption expenditures on income, household size, an indicator variable for an elderly household member, and a set of indicator variables for capital income above or below various thresholds. The $\$ 2,500$ threshold had the highest explanatory power of the thresholds we considered. 


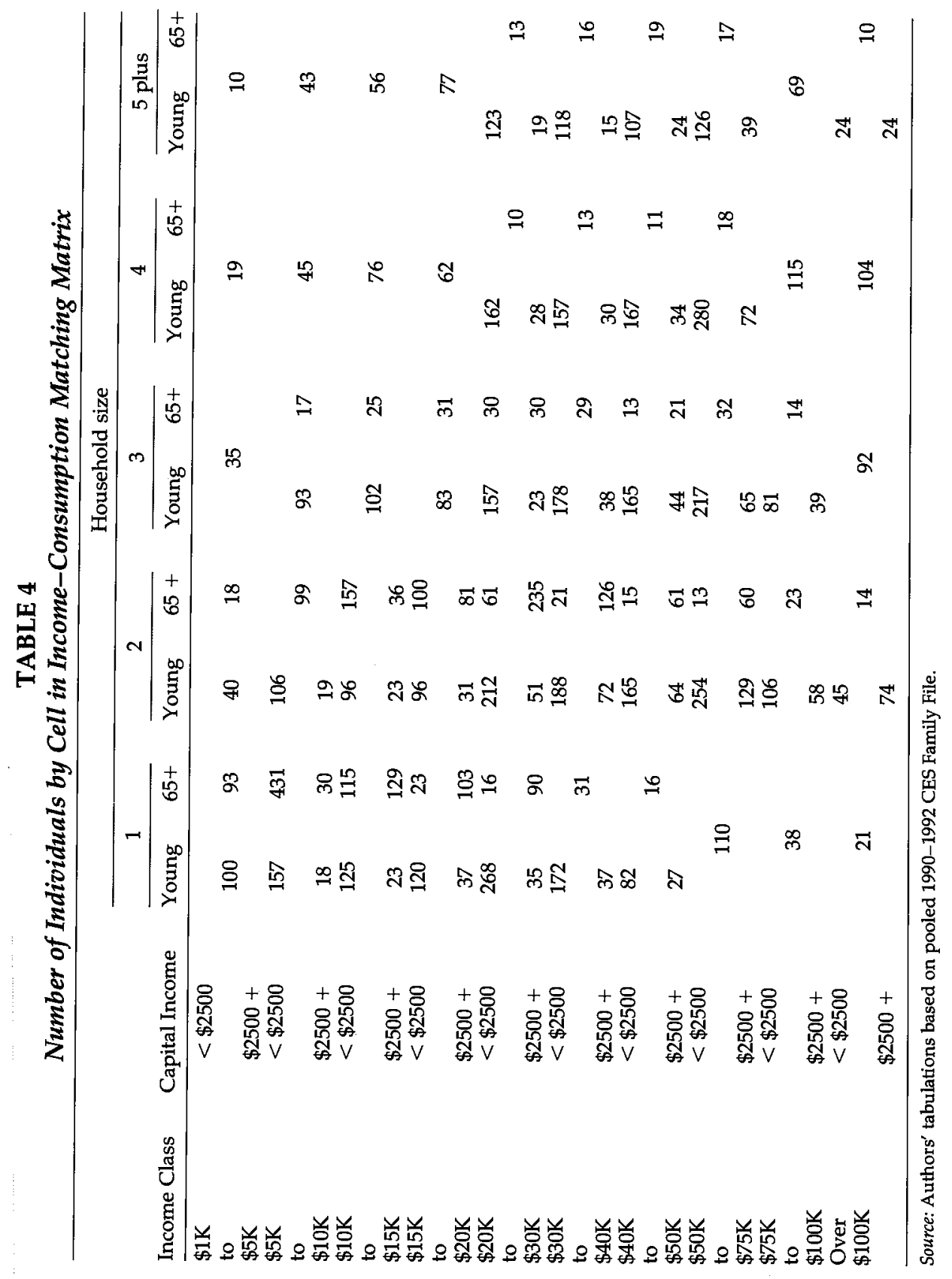


TABLE 5

Ratio of Consumption to Income

consumption class

\begin{tabular}{lcccc}
\hline & $\begin{array}{c}\text { Returns } \\
\text { (millions) }\end{array}$ & $\begin{array}{c}\text { Total } \\
\text { consumption }\end{array}$ & $\begin{array}{c}\text { Total } \\
\text { income }\end{array}$ & $\begin{array}{c}\text { Consumption } \\
\text { to income } \\
\text { ratio }\end{array}$ \\
\hline $0-5 \mathrm{k}$ & 6.2 & 3,362 & 3,957 & 0.850 \\
$5 \mathrm{k}-10 \mathrm{k}$ & 14.1 & 7,677 & 9,889 & 0.776 \\
$10 \mathrm{k}-15 \mathrm{k}$ & 17.5 & 12,532 & 17,059 & 0.735 \\
$15 \mathrm{k}-20 \mathrm{k}$ & 16.1 & 17,430 & 22,967 & 0.759 \\
$20 \mathrm{k}-30 \mathrm{k}$ & 25.4 & 24,710 & 32,446 & 0.762 \\
$30 \mathrm{k}-40 \mathrm{k}$ & 16.7 & 34,561 & 45,420 & 0.761 \\
$40 \mathrm{k}-50 \mathrm{k}$ & 9.5 & 44,548 & 57,708 & 0.772 \\
$50 \mathrm{k}-75 \mathrm{k}$ & 9.0 & 59,503 & 73,005 & 0.815 \\
$75 \mathrm{k}-100 \mathrm{k}$ & 2.1 & 84,958 & 103,901 & 0.818 \\
$100 \mathrm{k}-200 \mathrm{k}$ & 1.3 & 130,126 & 177,114 & 0.735 \\
Over 200k & 0.3 & 391,764 & 699,141 & 0.560 \\
& & & & \\
income class & & & & \\
\hline
\end{tabular}

\begin{tabular}{lccrc}
\hline & $\begin{array}{c}\text { Returns } \\
\text { (millions) }\end{array}$ & $\begin{array}{c}\text { Total } \\
\text { consumption }\end{array}$ & $\begin{array}{c}\text { Total } \\
\text { income }\end{array}$ & $\begin{array}{c}\text { Consumption } \\
\text { to income } \\
\text { ratio }\end{array}$ \\
\hline $0-5 \mathrm{k}$ & 9.8 & 10,250 & 2,222 & 4.614 \\
$5 \mathrm{k}-10 \mathrm{k}$ & 13.2 & 12,246 & 7,583 & 1.615 \\
$10 \mathrm{k}-15 \mathrm{k}$ & 12.4 & 15,163 & 12,506 & 1.212 \\
15k-20k & 11.7 & 18,040 & 17,487 & 1.032 \\
$20 \mathrm{k}-30 \mathrm{k}$ & 19.4 & 22,450 & 24,662 & 0.910 \\
30k-40k & 13.9 & 28,074 & 34,747 & 0.808 \\
$40 \mathrm{k}-50 \mathrm{k}$ & 10.7 & 33,328 & 44,760 & 0.745 \\
$50 \mathrm{k}-75 \mathrm{k}$ & 15.4 & 41,445 & 60,484 & 0.685 \\
$75 \mathrm{k}-100 \mathrm{k}$ & 5.8 & 52,697 & 85,342 & 0.617 \\
100k-200k & 4.0 & 68,812 & 128,786 & 0.534 \\
Over 200k & 1.1 & 175,492 & 475,234 & 0.369 \\
\hline
\end{tabular}

Source: Authors' tabulations using Tax File-CPS-CES merged file as described in the text. Income concept used includes the imputed value of owner occupied housing in excess of out-of-pocket housing expenses, and medical expenses that are not out of pocket. The entries in the last row indicate the ratio of total consumption to total income in the class, not the average ratio across households.

treme. There are many households in low income categories with imputed consumption several times greater than their income. This primarily reflects the relationship of consumption and income in the CES data file, rather than a problem that is created by our matching algorithm.

Table 5 presents summary information on total consumption (C), income including transfer payments and imputations $(Y)$, and the ratio of 
consumption to income for households in various consumption and income categories. This tabulation is based on the household records in our expanded Tax File-CPS data file, with consumption values imputed from the CES. The two imputations that we include in our income measure in Table 5 and all subsequent tables are the value of space rent on owner-occupied housing (in excess of cash housing outlays), and the value of health care paid for by third parties such as employer-provided health insurance or government health insurance programs. These items are included in consumption, and excluding them from income would overstate the consumption-to-income ratio.

The table shows consumption-to-income ratios for households ranked by total consumption as well as income. The upper panel of Table 5 shows some variation in the consumption to income ratio across consumption categories. For households consuming less than $\$ 5,000$ per year, the ratio of total consumption to total income is 0.85 . The ratio for higher consumption households varies between 0.74 and 0.82 , with the exception of very-high-consumption ( $\$ 200,000$ + per year) households, for whom consumption as a share of income drops to 0.56 . When households are ranked by income, the $\mathrm{C} / \mathrm{Y}$ ratio declines as income rises. The $C / Y$ ratio at low income levels is substantially greater than unity. The average value for households with incomes below $\$ 5,000$ is 4.61 , and this statistic is an important determinant of some of the distributional comparisons that we report later in the paper. Total consumption exceeds reported income in income categories up to $\$ 20,000$ per year. At very high income levels, the $\mathrm{C} / \mathrm{Y}$ ratio falls to about one-third.

There are several possible explanations for the high consumption-toincome ratios at low income levels. They may reflect measurement error in consumption or income, or under-reporting of income by these households. Branch (1994) discusses the quality of income reports in the CES, and indicates that while property income appears to be under-reported, other income reports seem consistent with data from, for example, the Current Population Survey. If this $C / Y$ pattern is due to unreported income or income from the "underground economy," the implications for our distributional analysis depend on how the income is spent. If unreported income is due to activities outside the current income tax reporting system, and it is spent on goods that are purchased through ordinary retail channels, then the tax burden on households with high reported $C / Y$ ratios may rise under the retail sales tax, because their transactions will be included in the tax base. If, however, the income from underground economic activities is spent on other underground activities that might not face the retail sales tax, then the reported $C / Y$ ratio may overstate the change in tax burdens. 
If unreported income is simply the result of response error on the part of survey participants, then actual income, and income tax liabilities, will be substantially greater than our analysis for low-income households suggests. In effect, some "low income" households should be classified in higher income groups. We are not aware of any direct evidence that can be used to evaluate these alternative explanations of high $\mathrm{C} / \mathrm{Y}$ ratios.

There are other explanations for the high $C / Y$ ratios besides unreported income, but they do not seem likely to account for what we observe. The high consumption-to-income ratios may reflect dissaving, although this seems 'unlikely since few of the households with high ratios report substantial asset holdings. They may represent the effect of inter-household transfers that are not well recorded in the CES. Unfortunately, the CES does not include sufficient information to enable us to develop potential corrections to what may be data measurement weaknesses, at least without strong additional assumptions. We hope to address this issue further in future work.

Although the Consumer Expenditure Survey is the best available data base on household consumption spending, it is plagued by problems of under-reported consumption. The aggregate measure of consumer spending in the National Income and Product Accounts, PCE, is substantially greater than the implied aggregate from the Consumer Expenditure Survey. ${ }^{12}$ Table 6 presents summary information on the level of consumption spending in our data file, the Consumer Expenditure Survey, and the national accounts. The aggregate values from our file and the CES files are not the same because our matching procedure imposes the income distribution from our Tax File-CPS merge file on the consumption-to-income ratios from the Consumer Expenditure Survey. Table 6 shows that consumption in both of the CES-based data sets is substantially below the level reported in the National Income and Product Accounts.

To address the problem of consumption under-reporting in the CES, we multiply all of the consumption flows in our data base by the ratio of personal consumption expenditures in the national accounts to the aggregate spending level in our Tax File-CPS data file. For education, for example, the NIPA aggregate is $\$ 66.0$ billion, and the total from the Tax File-CPS-CES merge is $\$ 54.3$ billion. We therefore scale up all education expenditures in the Tax File-CPS-CES merge by a factor of 1.215 to

12 The ratio of food expenditures in the CES to food expenditures in the national income accounts was 0.66 for 1991 . The analogous ratio for alcoholic beverages was 0.25 , for clothing and shoes 0.51 , for recreation 0.58 , and for education 0.71 . Further details on the matching between the CES and national income accounts aggregates may be found in Gieseman (1987) and U.S. Department of Labor (1995). 
TABLE 6

Aggregate Consumption: NIPA, CES Family File, and Synthetic Tax-CPSCES-NMES Merge File (\$billions)

\begin{tabular}{lrcc}
\hline & 1991 NIPA & CES aggregate & Tax-CPS-CES-NMES \\
\hline Food: on and off premises & 649.4 & 430.4 & 449.9 \\
Tobacco & 43.8 & 26.9 & 29.0 \\
Alcohol: off premises & 51.7 & 13.0 & 15.0 \\
Clothing and shoes & 211.2 & 107.3 & na \\
Gasoline and motor oil & 103.9 & 100.2 & 104.8 \\
Other transportation costs & 332.9 & 378.8 & na \\
Recreation & 292.0 & 169.6 & na \\
Education & 66.0 & 46.6 & 54.3 \\
Rent & 177.1 & 181.3 & 187.2 \\
Owner-occupied housing & 439.3 & 471.0 & 465.7 \\
Medical care & 668.7 & 154.0 & 672.2 \\
Total expenditures & $3,975.1$ & $2,678.6$ & $3,289.8$ \\
\hline
\end{tabular}

Source: NIPA data from January/February 1996 Survey of Current Business, CES tabulations from the CES Family File provided by John Sabelhaus, and Tax File-CPS-CES-NMES tabulations from the data file described in the text. Note that out-of-pocket medical costs of $\$ 155.0$ billion were reported in the CES but are not comparable to medical care costs reported in the NIPA, which includes payment by private and public insurance plans. The estimate of the rental value of owner-occupied housing in the CES is twelve times the reported monthly rental-equivalence value.

create the data file that we actually use for distributional analysis. We calculate this ratio for food at home, away from home, housing, alcohol expenditures, gasoline and motor oil, tobacco, charitable giving, education, medical care, and all other spending.

This expenditure expansion procedure assumes that the understatement of consumer expenditure in the CES is randomly distributed across households in various income classes. This assumption is unlikely to be valid. The Consumer Expenditure Survey top-codes income and consumption flows, and it is therefore likely to be particularly weak in describing the consumption behavior of high-income, highconsumption households. CES responses are top-coded at various levels, usually $\$ 100,000$ or $\$ 200,000$. Fifty-six of 5,065 households (1.1 percent) in the CES data file that we used were top-coded with respect to income. A somewhat higher fraction of households experienced some top-coding on particular consumption items. The top-coding problem makes it difficult to infer consumption patterns for households at the top of the income and wealth distribution. We are not aware of any data that would enable us to measure these consumption flows more accurately, but we hope to consider this issue in greater detail in future work. 
One further modification that we make to the CES data is concerned with owner-occupied housing. Our foregoing discussion of the retail sales tax base emphasized the prepayment analysis of owner-occupied housing and the difficulty of taxing imputed rent. This approach results in a smaller retail sales tax base. We compute each CES household's expenditure on owner-occupied housing by multiplying the reported market value of its home, as a share of the total market value of homes in our CES-Tax File data base, by our earlier estimate of the aggregate tax base that would result from taxing purchases of owner-occupied housing. This procedure does not exploit information on the households that actually bought homes, as the retail sales tax described in the first section would, but it does succeed in allocating the retail sales tax on owneroccupied homes to those households who own homes.

\subsection{Imputing Medical Expenditures of Tax File-CPS Households}

One aspect of consumption outlay that is poorly covered in the Consumer Expenditure Survey is medical spending. The survey records only out-of-pocket medical spending, so it omits all third-party payments by insurance companies, Medicare, and Medicaid. Since these expenditures would be included in the retail sales tax base, and since health care spending accounted for 14.8 percent of personal consumption expenditures in 1991, it is important to measure accurately this aspect of the consumer budget. To do this we combine information from another data base, the National Medical Expenditure Survey (NMES), with our data base from the Tax File and the Current Population Survey.

The NMES is a nationally representative household survey that contacted roughly 20,000 families during 1987, gathering information about demographic and economic characteristics, insurance coverage, and medical spending. We aggregate individual NMES respondents into "health insurance units": the family head, his or her spouse, any children under age 19, and full-time students until they reach age 23.

We define medical expenditures as the sum of out-of-pocket spending on medical care, spending that was reimbursed by private insurance policies including those provided by employers, and spending that was reimbursed through government insurance programs such as Medicare and Medicaid. We inflate the 1987 medical spending totals in the NMES to comparability with 1991 data by multiplying spending by the ratio of 1991 NIPA Medical Spending to 1987 NIPA spending.

Linking NMES and Tax File-CPS records requires a different matching algorithm than the one that we used to link the CES records, because the NMES does not include as much detail concerning income flows as the CES. We therefore compute household income using as close a measure 
to Form 1040 income as we can construct in the NMES, compute the analogous measure in the Tax File-CPS data, and construct cells of households according to household size, income, and whether there is anyone over age 65 in the household. Our resulting aggregate spending on medical care is 672.2 billion (see Table 6), compared with $\$ 668.7$ billion in the 1991 National Income and Product Accounts. We therefore multiply all medical outlays by 0.9948 to preserve comparability between our aggregates and the national income account totals.

\subsection{Imputing Corporate Income Taxes to Individual Tax Returns}

To evaluate the effect of replacing personal and corporate income taxes with a retail sales tax, it is necessary to allocate corporate income taxes to individual taxpayers. Our imputation of these taxes is based on Feldstein's (1988) approach, which assumes that the corporate income tax is born by all those who hold any type of capital assets, not just those who own claims on corporate capital. ${ }^{13}$ We focus on tax burdens when the economy reaches its new long-run steady state, rather than the asset price changes that might be associated with a shift from income to consumption taxation.

In 1991, corporate profit tax payments (CORPTAX), excluding payments by the Federal Reserve banks, totalled $\$ 89$ billion. Total capital income (CAPINC), which we define based on data in NIPA Tables 1.14 and 1.16, is the sum of net interest payments ( $\$ 448.0$ billion), corporate dividend payments ( $\$ 163.1$ billion), corporate undistributed profits ( $\$ 77.7$ billion), and rental income of persons after capital consumption adjustment ( $\$ 68.4$ billion). This implies total capital income of $\$ 757.2$ billion, or 16.0 percent of national income. Our definition of capital income excludes proprietor's income, which with inventory valuation and capital consumption adjustments totalled $\$ 362.9$ billion in 1991 . We exclude this because it is difficult to distinguish the labor and capital income components of proprietors' income. Adding proprietors' income to our foregoing definition would result in total capital income equal to 23.7 percent of national income, which accords with the "stylized fact" that capital income accounts for roughly one-quarter of national income.

Our algorithm for allocating corporate income taxes to households

13 This approach dates at least to Harberger's (1962) analysis, and represents the natural assumption given our focus on long-term steady-state distributional burdens. Feldstein (1988) observes that some previous studies combining corporate and personal income taxes have made different incidence assumptions. In particular, Pechman (1985) considered four possible allocations of the corporate income tax. Only one distributed the corporate income tax in proportion to total capital income, and even then, the definition of capital income did not accurately reflect the real incomes of capital owners. 
relies on three types of capital income received by households; dividends, interest, and rental income. We proceed in three steps. First, we adjust the national income accounts measures of interest receipts and retained earnings to reflect the inflation-induced devaluation of corporate debt, ${ }^{14}$ which reduces real interest income and raises returns to equity holders. We also transfer the income of pension funds from a component of household sector interest income to a corporate sector accrual, to reflect the prevalence of defined benefit pension plans. Feldstein (1988) discusses the rationale for each of these adjustments in more detail. These adjustments imply that our estimate of adjusted equity income, $\mathrm{EQINC}$, is

$$
\begin{aligned}
\text { EQINC }= & \text { Dividends }+ \text { Retained Earnings }+ \text { Pension Earnings } \\
& + \text { Inflationary Gains on Corporate Debt }
\end{aligned}
$$

and that other capital income, OTHCAPINC, equals

$$
\begin{aligned}
\text { OTHCAPINC }= & \text { Rental Income }+ \text { Interest Income } \\
& - \text { Inflationary Gains on Corporate Debt } \\
& - \text { Pension Earnings. }
\end{aligned}
$$

\section{By construction, CAPINC $=$ EQINC + OTHCAPINC.}

The second step in our algorithm involves computing the share of each type of capital income received by each potential tax filer in the Tax File-CPS data file. We refer to potential tax filers because some current nonfilers may have dividend, interest, or rental income, and they may consequently bear part of the corporate income tax. We use $\mathrm{DIV}_{\mathrm{i}}$ to denote dividend receipts by potential tax-filing unit $i, \mathrm{INT}_{\mathbf{i}}$ analogously to represent gross interest income, and $\mathrm{RENT}_{\mathrm{i}}$ to denote rental income. Tax returns report rental income from many types of properties, but there is no information on the rental value of owner-occupied housing. This is one of the most substantial components of rental income in the National Income and Product Accounts. We therefore use itemized deductions for property taxes to construct a proxy for the value of owneroccupied rental income for taxpayers who itemize. For taxpayers who do not itemize, and for nonfilers in our data base, we estimate the value of owner-occupied rental income on the basis of property tax payments

14 The market value of corporate debt is estimated by capitalizing net interest paid by corporations (NIPA Table 1.16, row 134b) by the BAA interest rate. The inflation rate is measured as the CPI inflation rate for all items less food and energy. 
imputed as part of the CES match. We sum the total amount of dividends $\left(\mathrm{DIV}_{\mathrm{i}}\right)$, interest $\left(\mathrm{INT}_{\mathrm{i}}\right)$, and rental income $\left(\mathrm{RENT}_{\mathrm{i}}\right)$ in the Tax FileCPS data base, and then compute the share of each component of this income received by each household as

$$
\begin{gathered}
\text { DIVSHR }_{\mathrm{i}}=\text { DIV }_{\mathrm{i}} / \Sigma_{\mathrm{j}} \mathrm{DIV}_{\mathrm{j}}, \mathrm{INTSHR}_{\mathrm{i}}=\mathrm{INT}_{\mathrm{i}} / \Sigma_{\mathrm{j}} \mathrm{INT}_{\mathrm{j}}, \\
\text { and RENTSHR } \\
=\mathrm{RENT}_{\mathrm{i}} / \Sigma_{\mathrm{i}} \mathrm{RENT}_{\mathrm{j}} .
\end{gathered}
$$

Finally, we allocate total corporate taxes between equity income and other capital income based on the shares of these two types of income in total capital income, and then apportion these taxes to individual households. Each potential tax filer is imputed corporate taxes of CORP $P_{i}$ based on the following formula:

$$
\begin{aligned}
\text { CORP }_{\mathrm{i}}= & {\left[\left(\frac{\text { OTHCAPINC } \left._{\text {CAPINC }}\right) \times\left(\text { INTSHR }_{\mathrm{i}}+\text { RENTSHR }_{\mathrm{i}}\right)+}{}\right.\right.} \\
& \left.\left(\frac{\text { EQINC }}{\text { CAPINC }}\right) \times \text { DIVSHR }_{\mathrm{i}}\right] \times \text { CORPTAX. }
\end{aligned}
$$

This procedure imputes to each dividend recipient taxes on the corporate earnings that made these dividends possible, as well as on an equiproportional share of the retained earnings generated in the corporate sector.

Table 7 shows the allocation of dividends, real net interest, property tax payments, as well as imputed corporate income tax revenues across households in different income categories. The income categories in this table are based on our expanded definition that includes imputations as in Table 5. The receipt of nonhousing capital income is concentrated among high-income households. Twenty percent of dividends are reported by tax-filing units with incomes above $\$ 500,000$. Households with incomes above $\$ 200,000$ report positive net interest receipts, while households in all income classes between $\$ 40,000$ and $\$ 200,000$ report negative net interest payments. Our imputation procedure assigns 24.0 percent of the corporate income taxes that are allocated to households to those with family income in excess of $\$ 500,000$. Nearly eighteen percent of total dividends are received by those with incomes of more than $\$ 1$ million.

Table 7 shows that imputed corporate income tax liabilities are small for most households. For the three-quarters of potential tax filers with incomes between zero and $\$ 40,000$, imputed corporate tax payments average only $\$ 302$ per year. For households with family incomes above $\$ 1$ million, however, the average imputed corporate tax is $\$ 250,196$ per 
TABLE 7

Dividends, Interest, Property Taxes Paid, and Imputed Corporate Income Taxes, by Income Class, 1991

\begin{tabular}{|c|c|c|c|c|c|}
\hline Income & $\begin{array}{c}\text { Tax units } \\
(1,000 s)\end{array}$ & Dividends & $\begin{array}{l}\text { Net nominal } \\
\text { interest } \\
\text { received }\end{array}$ & $\begin{array}{l}\text { Property } \\
\text { tax paid }\end{array}$ & $\begin{array}{l}\text { Imputed } \\
\text { corporation } \\
\operatorname{tax}\end{array}$ \\
\hline & & \multicolumn{4}{|c|}{ \$Billions by income class } \\
\hline $0-10 \mathrm{k}$ & 22,905 & 1.2 & 3.4 & 3.0 & 2.7 \\
\hline $10-20 \mathrm{k}$ & 24,151 & 3.1 & 10.6 & 7.4 & 7.6 \\
\hline $20-30 \mathrm{k}$ & 19,350 & 3.9 & 9.0 & 8.6 & 7.8 \\
\hline $30-40 \mathrm{k}$ & 13,913 & 4.4 & 2.8 & 8.9 & 6.1 \\
\hline $40-50 \mathrm{k}$ & 10,684 & 5.5 & -0.8 & 8.7 & 5.5 \\
\hline $50-75 \mathrm{k}$ & 15,350 & 12.0 & -13.8 & 18.2 & 7.8 \\
\hline $75-100 \mathrm{k}$ & 5,794 & 7.5 & -9.1 & 9.8 & 4.2 \\
\hline $100-200 \mathrm{k}$ & 4,011 & 13.5 & -4.7 & 10.2 & 10.8 \\
\hline $200-500 \mathrm{k}$ & 914 & 9.0 & 10.8 & 3.8 & 10.1 \\
\hline $500-1,000 \mathrm{k}$ & 141 & 4.5 & 8.4 & 1.1 & 5.8 \\
\hline Over $1,000 \mathrm{k}$ & 64 & 12.2 & 25.0 & 0.9 & 16.0 \\
\hline \multirow[t]{2}{*}{ Total } & 118,297 & 79.1 & 54.0 & 81.4 & 89.0 \\
\hline & $\begin{array}{c}\text { Tax units } \\
(1,000 \mathrm{~s})\end{array}$ & \multicolumn{4}{|c|}{ Mean values per tax unit } \\
\hline 0-10k & 22,905 & 51 & 152 & 131 & 119 \\
\hline $10-20 \mathrm{k}$ & 24,151 & 129 & 440 & 308 & 314 \\
\hline $20-30 k$ & 19,350 & 201 & 466 & 446 & 405 \\
\hline $30-40 \mathrm{k}$ & 13,913 & 317 & 200 & 639 & 440 \\
\hline $40-50 \mathrm{k}$ & 10,684 & 515 & -78 & 818 & 516 \\
\hline $50-75 \mathrm{k}$ & 15,350 & 783 & -897 & 1,186 & 505 \\
\hline $75-100 k$ & 5,794 & 1,303 & $-1,575$ & 1,688 & 732 \\
\hline $100-200 \mathrm{k}$ & 4,011 & 3,355 & -117 & 2,541 & 2,702 \\
\hline $200-500 \mathrm{k}$ & 914 & 9,831 & 11,795 & 4,169 & 11,090 \\
\hline $500-1,000 \mathrm{k}$ & 141 & 31,765 & 59,277 & 7,481 & 41,284 \\
\hline Over $1,000 \mathrm{k}$ & 64 & 189,824 & 390,498 & 13,843 & 250,196 \\
\hline Mean & & 669 & 457 & 688 & 752 \\
\hline
\end{tabular}

Source: Authors' tabulations from Tax File-CPS data file. Amounts for taxpayers with negative income are included in totals, but are not otherwise shown. See text for further discussion. 
year. Recognizing corporate income taxes is therefore critical to evaluating the distributional effects of retail sales tax plans that eliminate these taxes.

\subsection{Imputing Estate and Gift Tax Revenues to Individuals}

Many proposals for replacing the income tax with a consumption tax also call for elimination of the estate and gift tax. Federal receipts from these taxes totalled $\$ 11.0$ billion in 1991. Eliminating these taxes would require a higher retail sales tax rate than if only the income tax were replaced. Distributional analysis also requires an allocation scheme for imputing estate and gift tax payments to potential tax filers. Because the federal estate and gift taxes only apply to estates valued in excess of $\$ 600,000$, we assume that households that bear this tax have substantial capital assets and associated capital income. ${ }^{15}$ We define capital income (CAP) as the sum of dividends, taxable interest, capital gains, taxexempt bond interest, income from trusts, partnerships, Subchapter S corporations, rents, and royalties. We then construct another variable, CAP30K, which equals the excess of capital income above $\$ 30,000$ :

$$
\begin{aligned}
\mathrm{CAP} 30 \mathrm{~K}=0 & \text { if } \mathrm{CAP}<\$ 30,000 \\
\mathrm{CAP}-30,000 & \text { if } \mathrm{CAP}>\$ 30,000 .
\end{aligned}
$$

To place the $\$ 30,000$ cutoff in perspective, a household would have to have held approximately $\$ 370,000$ in Treasury bonds, yielding the 1991 nominal 30-year Treasury bond rate of 8.14 percent, to generate this flow of capital income. Since most households with this level of financial assets are also homeowners, their taxable estate would be greater than their financial asset holdings.

We allocate the burden of estate and gift taxes in proportion to each household's share of CAP30K, but limit out imputation to households with someone over the age of $65 .{ }^{16}$ This approach corresponds loosely to an attempt to calculate the expected estate and gift tax payment for a household in any year. ${ }^{17}$ The exact expression for this expected value is (Probability of Death Within the Year) $\times$ (Estate Tax Due Conditional on Death This Year). Since we do not have information on taxpayer ages,

15 Our algorithm may under-estimate estate tax liabilities for some households with substantial owner-occupied real estate holdings but no other assets that generate taxable capital income.

16 This procedure implicitly assumes that the estate tax is proportional, and neglects the rate structure progressivity of the tax.

17 The U.S. Congress Joint Committee on Taxation (1993) develops a similar procedure, based on capital income and age, for allocating estate and gift tax burdens. 
except insofar as we know if there is someone over age 65 in the tax filing unit, we cannot use age-specific mortality rates in the first term of this product. We also do not know the tax filer's total wealth, and thus whether estate tax would in fact be due if the tax filer died this year. We crudely approximate mortality risk by assuming that it is zero for those under age 65 , and positive but equal for all taxpayers with someone over age 65 in the tax filing unit. This analysis assumes that the burden of the estate tax falls on the decedent.

We let $\mathrm{CAP3OK}_{\mathrm{i}}$ denote the value of CAP30K for household $i$, and AGE $65_{i}=1$ for tax filers who claim an exemption on their tax return for an aged tax filer, and for nonfilers who report someone over age 65 in their CPS household. We then set $w_{i}=A_{\text {GE65 }} \times$ CAP30K $_{i} / \Sigma_{j}$ AGE65 $_{j} \times$ CAP30K $K_{i}$. Note that $w_{i}$ will equal zero for most potential tax filing units. We then define each tax filing unit's share of aggregate estate and gift taxes as

$$
\operatorname{E\& GTAX}_{\mathrm{i}}=\mathrm{w}_{\mathrm{i}} \times(\text { Federal Estate \& Gift Tax Receipts }) .
$$

Table 8 shows the resulting allocation of estate and gift taxes across households with various levels of family income. The table shows, not

\section{TABLE 8}

\section{Distribution of Imputed Estate Tax Liabilities, by Income Class}

\begin{tabular}{lccc}
\hline & & \multicolumn{2}{c}{$\begin{array}{c}\text { Combined estate } \\
\text { and gift tax liability }\end{array}$} \\
\cline { 3 - 4 } Income & $\begin{array}{c}\text { Tax units } \\
(1,000 \mathrm{~s})\end{array}$ & $\begin{array}{c}\text { \$Billions } \\
\text { by income class }\end{array}$ & $\begin{array}{c}\text { Mean } \\
\text { per tax unit }\end{array}$ \\
\hline $0-10 \mathrm{k}$ & 22,905 & - & 1 \\
$10-20 \mathrm{k}$ & 24,151 & - & 1 \\
$20-30 \mathrm{k}$ & 19,350 & - & 2 \\
$30-40 \mathrm{k}$ & 13,913 & 0.1 & 5 \\
$40-50 \mathrm{k}$ & 10,684 & 0.1 & 11 \\
$50-75 \mathrm{k}$ & 15,350 & 0.8 & 55 \\
$75-100 \mathrm{k}$ & 5,794 & 0.9 & 163 \\
$100-200 \mathrm{k}$ & 4,011 & 2.4 & 591 \\
$200-500 \mathrm{k}$ & 914 & 2.1 & 2,281 \\
$500-1,000 \mathrm{k}$ & 141 & 1.1 & 8,117 \\
Over 1,000k & 64 & 3.2 & 50,590 \\
All tax units & 118,296 & $\$ 11.0$ & 93 \\
\hline
\end{tabular}

Source: Authors' tabulations based on imputation algorithm described in the text. Entries reflect average imputed estate and gift tax liability per potential income tax filing unit in each income category. Amounts for taxpayers with negative income are included in totals, but are not otherwise shown. See text for further discussion. 
surprisingly, that our imputation procedure assigns most of the burden of estate and gift taxes to high income households. Twenty-nine percent of the estate and gift tax burden is allocated to households with incomes of $\$ 1$ million or more; another 10 percent is assigned to households with incomes between $\$ 500,000$ and $\$ 1,000,000$. Households with incomes below $\$ 30,000$ per year are assigned essentially no tax liability under the estate tax.

\subsection{Imputing Wage Income from Form 1040 Joint Filers to Household Members}

One issue that arises in analyzing a retail sales tax as a replacement for both the income and payroll taxes concerns the measurement of current payroll tax liabilities. This requires information on the earnings of each person in a household. Since Form 1040 only reports the total amount of wage income earned by the tax filing unit, it is not possible to distinguish earnings by individuals filing joint returns. We therefore use data from the Current Population Survey and match Tax File households with more than one potential earner to CPS households on the basis of total wages, family size, the presence of more than $\$ 2500$ of capital income, and the presence in the household of someone aged 65 or above. We use the same approach that we developed in matching the CES to the Tax File. We allocate CPS households to cells, identify the cell corresponding to each Tax File household, randomly select one of the CPS households in this cell, and use the ratio of wage income for the two earners in the CPS household to allocate the total wage income of the Tax File household between the two earners.

\section{COMPARING THE DISTRIBUTION OF TAX BURDENS: INCOME TAXES AND RETAIL SALES}

\section{TAXES}

We use our expanded Tax File to evaluate a tax reform that replaces the federal income tax with a national retail sales tax. We consider four possible retail sales taxes: one without any exemptions, one with an exemption for food, one with an exemption for food, medical services, and housing, and one coupled with a "demogrant" system that would provide cash assistance to reduce the average tax burden on low income households. We consider a retail sales tax that replaces only the federal income tax, as well as one that replaces both the federal income tax system and the payroll tax.

There are several ways to categorize households in creating distribu- 
tion tables to illustrate the effects of tax reform. Barthold and Jack (1995) discuss a range of issues that arise in selecting the "income concept" that should be used for classifying households in a distribution table; the U.S. Congress Joint Committee on Taxation (1993) also reviews this issue. "Snapshot" annual income, which shows a household's income during a single year, suffers from a number of limitations as a measure of household well-being. Income varies from one year to the next, and one year's income may not reflect a household's position in the lifetime income or well-being distribution. ${ }^{18}$ Yet the income measures in the Tax File, and from the Current Population Survey, are exclusively snapshot income measures.

One attractive alternative to annual income, suggested by Poterba (1989) and subsequently applied by Metcalf (1994) and Caspersen and Metcalf (1994), among others, suggests the use of consumption rather than income to measure "lifetime income" in distribution analysis. ${ }^{19}$ In light of the extreme values of the consumption-to-income ratio that we observe in the CES data base, the use of total spending rather than income as a measure of household well-being has substantial appeal. We therefore begin with this approach to distributional comparisons, and then present comparisons based on annual income classification.

Table 9 presents our central analysis of the comparative distribution of tax burdens under the current income tax system and a retail sales tax. The upper panel of the table shows the average taxes paid by households in each consumption category, while the lower panel shows the tax rate, measured as the ratio of tax payments to the household's total consumption.

The first column in Table 9 reports the number of potential tax filing units in each consumption category for 1991, while the second column shows the personal income tax liability for households in each group. ${ }^{20}$ The entries in this column show that households with consumption

18 Studies that discuss the fluctuation in annual income include Davies, St. Hilaire, and Whalley (1984), Fullerton and Rogers (1993), Metcalf (1994), Poterba (1989), and Slemrod (1992).

19 Caspersen and Metcalf (1994) compare long-term average income from the Panel Survey of Income Dynamics, snapshot annual income, and total consumption as alternative bases for allocating households to distribution classes. They find that results from the long-term income measure fall between those with consumption and snapshot income. Fullerton and Rogers (1993) also develop an explicit measure of lifetime income for households.

${ }_{20}$ Our analysis follows the standard, if debatable, practice of using tax liabilities rather than a utility-based measure of welfare loss in describing the burden of taxes for different income groups. Barthold (1993) and Bradford (1995) provide excellent introductions to many of the difficulties with this approach to distribution analysis. Fullerton and Rogers (1993) use utility-based measures. 


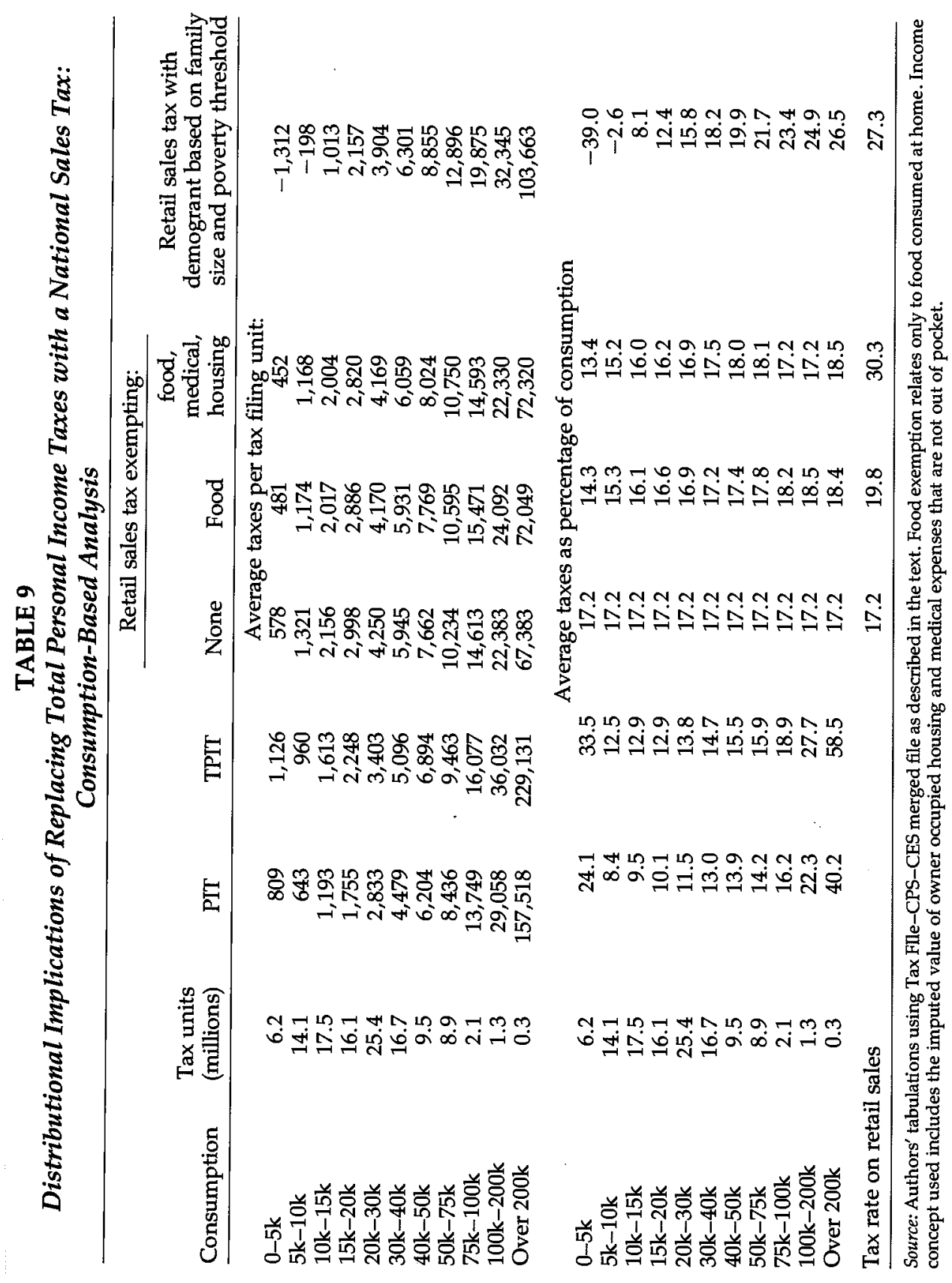


between $\$ 5,000$ and $\$ 10,000$ per year make average income tax payments of $\$ 643$ per year, while their average total income tax liability, including corporate income taxes and the estate and gift tax, is $\$ 960$ per year. Households with lower consumption levels $(0-\$ 5,000)$ paradoxically report higher average tax burdens than those in the $\$ 5,000-10,000$ category; in part this reflects the greater incidence of households with substantial capital income in this group. It also suggests that households with very low reported consumption may have consumption that is measured with error.

The average income tax and total tax burden rises with household consumption. The average income tax burden for households with consumption in excess of $\$ 200,000$ per year is $\$ 157,518$. Including the corporate and estate tax burdens on such households raises their total tax liability to $\$ 229,131$ per year.

The fourth through sixth columns of Table 9 show the distribution of average tax burdens under the retail sales tax. Column four describes the retail sales tax with the broadest base, with no exemptions for particular sub-categories of consumption. The required retail sales tax rate in this case is 17.2 percent. The average tax burden on households near but not at the bottom of the consumption distribution increases relative to the tax burden under the income tax system. For the somewhat unusual group reporting consumption of less than $\$ 5,000$ per year, however, the tax burden declines substantially with the adoption of the retail sales tax. For households with consumption between $\$ 5,000$ and $\$ 10,000$ per year, the average tax burden rises from $\$ 960$ to $\$ 1,321$. At very high consumption levels, the tax burden is lower under the retail sales tax than under the income tax. Those households with consumption between $\$ 100,000$ and $\$ 200,000$ per year, for example, make average tax payments of $\$ 36,032$ under the income tax system. They would pay an average of $\$ 22,383$ under the retail sales tax.

The next two columns of Table 9 illustrate the effect of excluding food, or food, medical care, and housing, from the retail sales tax base. The effect of these changes on the distribution of tax burdens is relatively small, although the required retail sales tax rates rise to 19.8 percent and 30.3 percent, respectively. While these exemptions reduce the tax burden on low consumption households and raise the share of the retail sales tax that is paid by high consumption households, the effects are muted. Even exempting the three "necessities" from the retail sales tax base, the average tax burden on households with consumption between $\$ 5,000$ and $\$ 10,000$ declines by only $\$ 153$, from $\$ 1,321$ to $\$ 1,168$ in comparison with the broadest-base retail sales tax. This is because the CES data indicate that the share of household expenditures allocated to these 
consumption categories changes relatively little as one moves up the consumption distribution. Exempting particular goods from the retail sales tax base therefore proves to be a weak method of altering the distribution of tax burdens across households.

The last column in Table 9 shows the impact of switching from the current income tax system to a retail sales tax with a demogrant provision that would provide each household with a lump-sum transfer equal to the retail sales tax rate times the U.S. Bureau of the Census (1992) poverty threshold for a family of their size. ${ }^{21}$ The total retail sales tax burden on low-consumption households declines, and in some cases becomes negative, with this demogrant proposal. The retail sales tax burden on high consumption households is also increased by the demogrant, because financing the demogrant requires a higher retail sales tax rate. These results suggest that demogrants are powerful instruments for altering the distribution of tax burdens across households in different consumption categories.

One feature of the demogrant that is not illustrated in our tables is its differential effect on families of different sizes. The demogrant will reduce the effective tax burden by more on large households than on small households, conditional on their expenditure or income level.

The lower panel of Table 9 presents information on the "average tax rate" $^{\prime \prime}$ paid by households in different consumption classes. These tax rates are defined as the ratio of taxes paid to the measure of household well being, in this case total consumption outlays. The results provide an alternative perspective on the basic findings that are shown in the upper panel of the table. When the retail sales tax is paired with a demogrant, the average tax rate is negative for households at the bottom of the consumption distribution, -2.6 percent, for example, for those with consumption between $\$ 5,000$ and $\$ 10,000$, and it rises as household consumption rises to approach 26.5 percent, the statutory retail sales tax rate, at the highest consumption levels. For the broad-based retail sales tax without any exemptions and without a demogrant, the tax rate on household consumption is the same for households in all consumption categories.

Table 10 uses a more traditional annual income classifier to allocate households to categories in the distribution table. The income concept we use includes the imputed value of rent from owner-occupied housing, in excess of cash housing outlays, as well as our estimate of the

${ }^{21}$ It might be difficult to administer such a demogrant if the current income tax administrative structure were largely dismantled. Some advocates of fundamental tax reform suggest that this is an important goal of reform; this may affect the set of distributional policies that can be considered in a reform. 


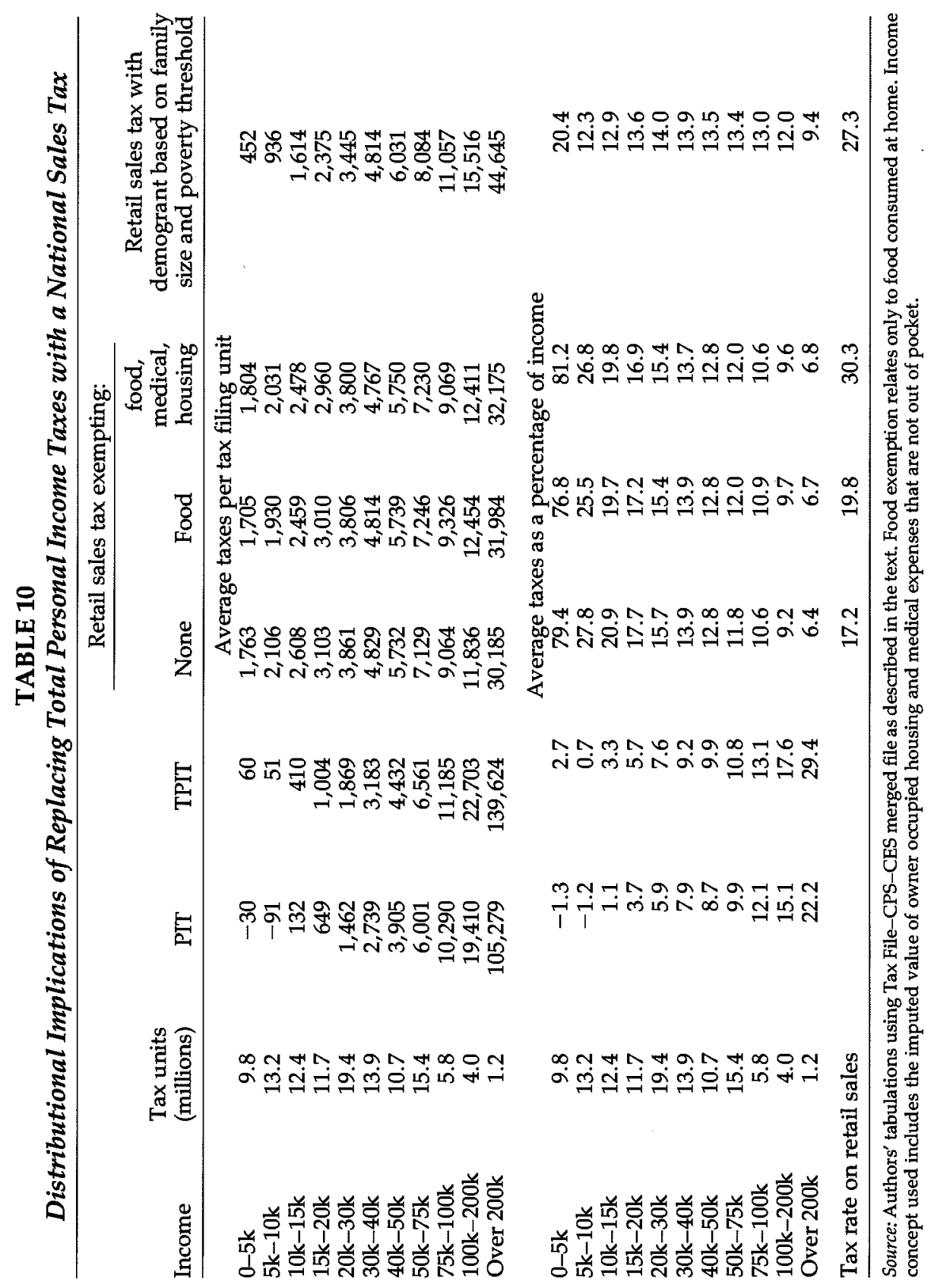


value of medical care paid for by third parties (i.e. not paid for out-ofpocket). The broad pattern of results is similar to that in Table 9, but there are several notable differences. First, when households are ranked by income, those in the lowest income categories show very small income tax liabilities under the current system, primarily as a result of the Earned Income Tax Credit. Because many very low income households report substantial consumption outlays, the increase in average tax burdens between the income tax and the retail sales tax is substantial. For households with incomes between $\$ 5,000$ and $\$ 10,000$, for example, average tax liability rises from a small value, $\$ 51$ dollars, under the income tax system, to a substantial value, $\$ 2,106$, under the retail sales tax without any exemptions.

Second, the decline in tax burdens on high income households is even sharper than the decline for high consumption households when the income tax is replaced by the retail sales tax. Because high income households account for a lower share of consumption than income, their relative tax burdens fall under the retail sales tax. Households with incomes in excess of $\$ 200,000$ per year are estimated to pay an average of $\$ 139,624$ under the current income tax, but their tax burden falls to $\$ 30,185$ under the broadest base retail sales tax. Households with incomes below $\$ 50,000$ are estimated to pay more under the retail sales tax than under the current income tax system, while those with incomes above $\$ 75,000$ are estimated to face lower tax bills under the retail sales tax.

Third, the effect of the demogrant scheme is similar when households are categorized by income and by consumption. For households with total income between $\$ 5,000$ and $\$ 10,000$, for example, the average tax burden with the demogrant is 12.3 percent, compared with 27.8 percent for the retail sales tax without a demogrant. For high income households tax burdens correspondingly rise, reflecting the higher tax rate that is associated with the demogrant-inclusive retail sales tax.

The lower panel of Table 10 presents information on average tax rates under the various tax proposals. In this case the denominator for the tax rate calculations is total household income before taxes. The broad pattern of results resembles those for average tax burdens, and the effects of the demogrant plan are clear in these data as well. For those with incomes between $\$ 100,000$ and $\$ 200,000$, the tax rate is 9.2 percent under the broadest-based retail sales tax, and 12 percent with the demogrant.

Tables 11 and 12 present similar calculations for the case in which the retail sales tax replaces both the federal income tax and the payroll tax. The broad pattern of distributional results is similar to that in Tables 9 and 10. The retail sales tax rates that are required to raise as much revenue as the current payroll and income tax systems are 


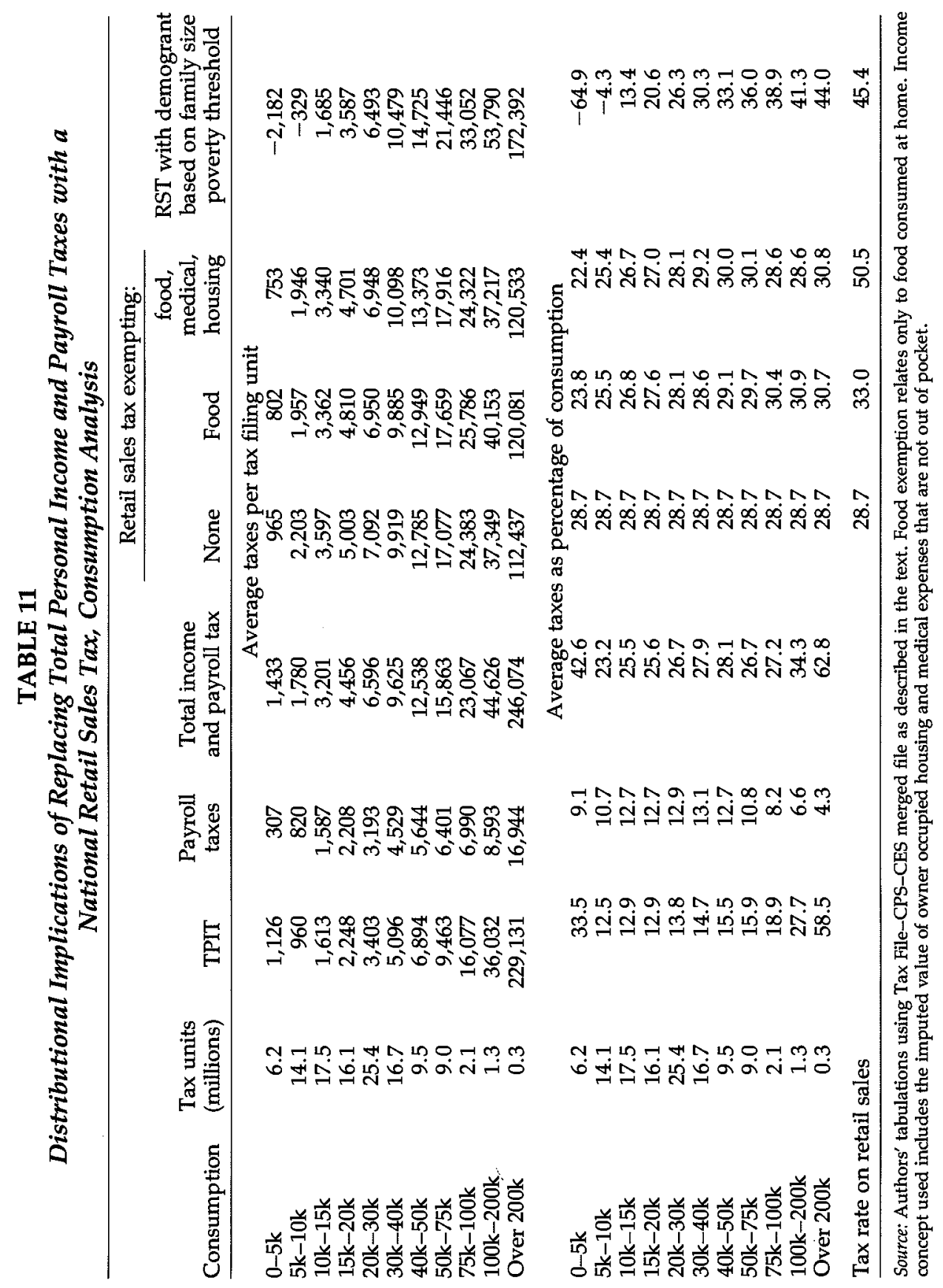




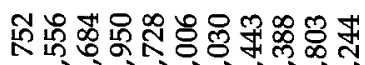
नंत लं

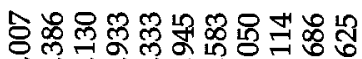

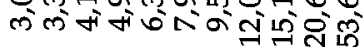
节

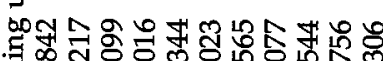

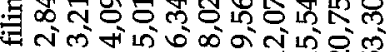
I 家

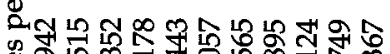

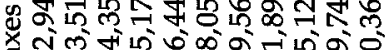

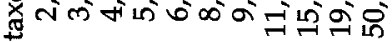
$\stackrel{80}{80}$ 2

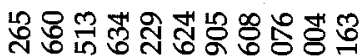

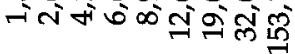

mo cona Han

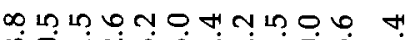

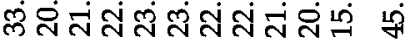
?

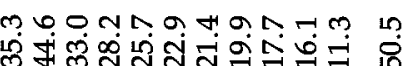

व)

ลิ่

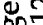
II $\mathbb{U}^{\circ}$

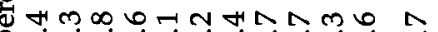
๘ g

离

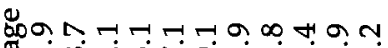

ปึ่ $\stackrel{2}{4}$

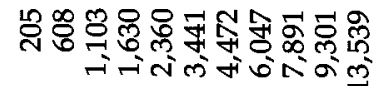

nom mo a 00 m

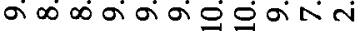

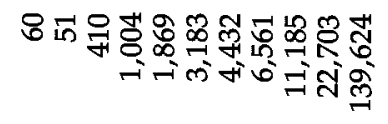

NNMN तं ம்

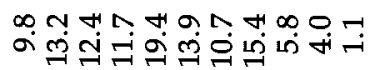

कં

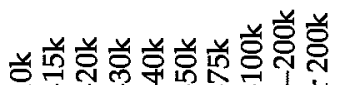
ถ⿻

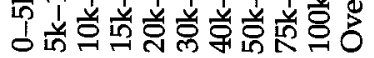


greater than those that are required when only the income tax is replaced by the retail sales tax.

\section{STEADY-STATE VERSUS TRANSITION ISSUES IN DISTRIBUTION ANALYSIS}

Our analysis focuses on the long-run steady state comparison between the distribution of tax burdens under the retail sales tax and the current income tax system. In moving from the current tax code to the new steady state, however, there may be important transitional considerations that largely determine the short-run incidence of tax reform. Many of these issues involve differences in asset holdings across households, and the effect of tax reform on asset values. Because of difficulties in linking information on asset holdings to the Tax File-CPS data base, we have not considered these issues. Other transitional issues, as well as long-run issues, hinge on whether households receive "indexed" transfer payments, and how the real value of these transfers would respond to the adoption of a retail sales tax.

In this section we address several topics related to the transition from an income tax to a consumption tax. We begin by considering the price level response to replacement of an income tax with a retail sales tax, and we then consider other issues including the response of asset prices to the tax reform.

\subsection{Consumer Prices and the Retail Sales Tax}

The consumer price impact of switching from an income tax to a retail sales tax is important for two distinct reasons. The first is a short-run transition issue, concerning the macroeconomic effects of the tax switch. The second is a long-run incidence issue, concerning the burden of the retail sales tax on the recipients of potentially-indexed government transfer payments. We begin with a brief discussion of the short-run transition issues.

To understand how retail prices would respond to the tax reform considered in the last section, consider the simple analytics of substituting a retail sales tax for an income tax in a stylized economy without saving or investment. Assume that the economy is initially in equilibrium with an income tax rate of 20 percent, so that if nominal pretax wages equal 100 , net-of-tax wages as well as consumption equal 80 , while tax revenue and government spending equal 20 . Since the government purchases 20 units of the final good, consumers purchase 80 . Now consider replacing the income tax with an equal-yield 25 percent retail sales tax, and assume that nominal wages remain at 100 , so that after-tax wages are now 100 . If 
producer prices do not change, but producers simply add the retail sales tax to the amount charged to consumers, then consumers will spend 100, but 20 of that amount will represent sales tax, and 80 will represent a payment to producers. Total taxes and government consumption will again equal 20 , so that producers will still receive 100 from their total sales, after remitting sales taxes of 20 to the government. The producers' total receipts under the sales tax, including the sales tax collections, equal 120 , since government purchases of 20 are not taxed and are added to consumer tax-inclusive spending of 100 . Under the income tax regime, producers received 100 from their sales. They may have remitted 20 to the government as withheld income tax for their workers.

In this example, all relative prices remain the same in these two equilibria. The critical determinant of real activity is the after-tax real wage, $(1-T) \mathrm{w} / \mathrm{p}(1+\theta)$, where $T$ denotes the income tax rate, $\theta$ the retail sales tax rate, $\mathrm{w}$ the nominal pre-tax wage, and $\mathrm{p}$ the producer price level. ${ }^{22}$ The consumer price level, defined inclusive of retail sales taxes, will increase in this scenario because, with $p$ fixed, $p(1+\theta)$ rises when $\theta$ changes from zero to a positive value.

How a switch from direct to indirect taxation affects the demand for nominal money balances is more subtle than the question of whether it would raise the tax-inclusive Consumer Price Index (CPI). In many standard models, the foregoing analysis suggests that an increase in the money supply is needed to accommodate the change to a new tax system. Consider the case in which the demand for nominal money balances $(f)$ depends on the nominal value of consumption transactions, $\mathrm{C} \times \mathrm{p} \times(1+\theta)$, and in particular includes the value of sales taxes but not income taxes. In this case money market equilibrium requires that

$$
\mathrm{M}=\mathrm{f}(\mathrm{C} \times \mathrm{p} \times(1+\theta)
$$

where $M$ denotes nominal money supply and $r$ denotes the interest rate. The tax switch from income to consumption taxes, which increases $\theta$, would require a one-time increase in the nominal money supply to avoid a need for a decline in nominal producer prices. Mankiw and Summers (1986) provide a more complete discussion of the choice of variables in the money demand function, and the implications of alternative assumptions for the analysis of fiscal policy reforms. Our analysis abstracts from the effect of the after-tax interest rate on money demand; this interest rate might rise as a consequence of tax reform.

22 Hall (1996) and Bradford (1996) discuss these transition dynamics in some detail. Poterba, Rotemberg, and Summers (1986) present some evidence on the macroeconomic effects of Britain's income tax-to-consumption tax transition in the late 1970s. 
The critical maintained assumption in many standard specifications of money demand is that consumers require cash balances to pay retail sales taxes, but not to pay income taxes. If the appropriate scaling variable for nominal money demand is in fact $C \times p \times(1+\Theta)+T \times Y \times p$, where $Y$ denotes real income and $T$ the income tax rate, then a shift from income to consumption taxation might not require a monetary accommodation. This approach would argue for deflating nominal money balances not by the CPI including only sales taxes, but by a price index that included income taxes as well (Bull and Lindsey, 1996, discuss related issues). Further empirical work could usefully examine the relative effect of direct and indirect taxes on money demand.

Whether the consumer price index is measured inclusive of the retail sales tax rate but not the income tax rate can have important consequences for the long-term incidence of the tax reform. Many households receive government transfer payments that are indexed to the measured CPI. In our example above, if the consumer price index is calculated inclusive of the federal retail sales tax, then even if nominal producer prices do not adjust to the tax change, the measured consumer price index would rise. This will result in increased government spending on transfer programs, and it will reduce the tax burden on those who rely on these programs for their income. ${ }^{23}$ Our distributional analyses have not considered potential effects through this channel.

Calculating the CPI inclusive of the retail sales tax would also result in spurious disruption of the real value of many indexed transfers in the private economy. Our earlier example illustrates that no change in nominal wages is needed to preserve the real purchasing power of labor income, since income taxes on wages are being replaced by sales taxes on purchases. Increasing nominal wages under indexed labor contracts, to reflect the rise in the tax-inclusive consumer price index, would therefore represent an increase in the real after-tax wage received by labor. One potential solution to disrupting nominal contracts as a result of this arbitrary distinction is to change the definition of the CPI to help maintain the intended meaning of index-linked contracts. A revised consumer price index, which included income taxes as part of the cost of living, could be introduced before the transition, eliminating most problems with indexed contracts. Poterba, Rotemberg, and Summers (1986) note that this was part of the transitional arrangement in the United Kingdom in 1979, when there was a significant shift from direct to indirect taxation.

${ }^{23}$ If transfer payments are not indexed, then those who receive transfer income that is not taxed under the current income tax would be worse off under the retail sales tax. 


\subsection{Asset Revaluation Effects}

One of the major incidence effects of a shift from income to consumption taxation is likely to be associated with the revaluation of claims to various assets. The real value of owner-occupied homes, of shares in corporations, and of debt claims could all be affected by a shift in the tax base. Households differ in their holdings of these assets, and correspondingly would face different gains or losses from tax reform. Gentry and Hubbard (1997) focus on these aspects of consumption tax incidence. Kotlikoff (1993) emphasizes transition effects as the critical determinant of the short-run incidence of replacing the income tax with a consumptionbased tax. He points out that switching instantaneously to a consumption tax places a substantial burden on households that have accumulated assets under the income tax system with the intention of consuming the principal from these assets in the future. Such households would have formulated their consumption plan on the assumption that they would not be taxed on their consumption, yet the switch to a consumption tax would in fact place a tax burden on such spending. ${ }^{24}$ The nature of these transition effects depends substantially on individual circumstances. Individuals who have accumulated assets in tax-deferred saving accounts, for example, would not face a shock to their prospective tax burden in the way that those who have accumulated in traditional after-tax accounts would.

This type of transition effect is best illustrated by considering an individual who owns a bond that promises a finite-lived stream of nominal future payments, consisting of interest and principal. When the income tax is replaced by the retail sales tax, assuming that the tax-inclusive consumer price index rises, the purchasing power of the bond's nominal principal repayments (but not the interest payments) falls. The reduction in future household consumption opportunities associated with such asset revaluations is not captured in our distribution tables. This implies that distribution tables of the type we have constructed do not reflect the substantial horizontal inequity across households within income or consumption cells that will be associated with the revaluation of the real purchasing power of portfolio assets. Because asset holdings are concentrated among

${ }^{24}$ This logic applies to planned consumption that would be financed from the principal value of assets held at the time of the transition, but not to consumption that would be financed from the future income generated by these assets. Someone who planned to use future interest income to finance their consumption would face a sales tax on their expenditure, but this would be offset by the reduced income tax burden on their interest income. No such offset applies to consumption financed by drawing down principal. Thus the consumption tax places the largest incremental burden on those who have accumulated assets and who plan to consume these assets soon. 
households with higher income and consumption levels, most of the asset revaluation effects would be concentrated among these households. Providing a more detailed analysis of this issue requires information on the patterns of asset holdings, consumption, and income across households.

\section{CONCLUSION AND FUTURE ISSUES}

We find that switching from the current income tax system to a national retail sales tax without direct transfers to low-income households can substantially alter the distribution of tax burdens. When households are ranked by their total consumption spending, which is our preferred method of constructing distribution tables, the burden of the retail sales tax is either proportional to consumption outlays, or rises as a share of outlays when the retail sales tax plan is coupled with a "demogrant" proposal. When households are ranked by annual income in constructing distribution tables, we find that the tax burden on high income households is generally lower under the retail sales tax than under the income tax. This pattern arises from the greater share of income that is devoted to consumption at low income levels, from the progressivity of the rate structure in the current personal income tax, in comparison with the flat rate embodied in a retail sales tax, and because the corporation income tax and estate and gift taxes, which are part of the income tax system, place substantially greater burdens on high-income than on low-income households. These results confirm the findings in other studies of comparative steady-state distribution of tax burdens, such as Gale, Houser, and Scholz (1996) and Metcalf (1994), which have focused only on the replacement of the individual income tax with a consumptionbased tax system.

In developing our distributional comparisons, we have substantially extended the capacity of the NBER TAXSIM model to address a range of tax reform options. We have linked the Individual Tax File with information on household consumption and medical spending. This data linkage is an essential step in moving beyond the analysis of income tax reforms, and considering changes in the tax base. It follows in the spirit of extended data bases that are used by various government agencies to analyze potential tax reforms.

Despite this advance, we have not surmounted many of the difficult issues that are associated with the analysis of distribution tables. These include the lack of information on income and expenditures over longer horizons, and the absence of general equilibrium feedback effects in our analysis. Bradford (1995) notes many of the shortcomings of this approach, and calls particular attention to the impact of these limitations 
on the apparent distribution of consumption-based rather than incomebased taxes.

The procedure we have used, which involves the construction of "cells" of similar households in the Tax File and other data bases, followed by imputation based on these cells, could in principle be applied to impute additional data to tax filing units. Two types of information would be particularly valuable: data on transitory versus permanent income, and data on household asset holdings. A number of studies have shown that indirect taxes are more regressive when households are categorized on the basis of their annual income than when they are allocated to income categories based on a measure of lifetime income, and underscored the need for a longer-term perspective in analyzing tax burdens. It would therefore be very useful to expand the current data base to include information on longer-term measures of household income. One option would involve using data bases that record multi-year income observations, such as the Panel Survey of Income Dynamics or the IRS tax return panel, to append information on multi-year income profiles to the Tax File.

We are less optimistic about the prospects for linking information on household asset holdings to data records in the Tax File. The most complete data source for asset holdings, the Survey of Consumer Finances (SCF), is a relatively small survey. Thus the problems that we encountered in creating cells based on households in the Consumer Expenditure Survey would be more severe with the SCF. We nevertheless hope to investigate the importance of these difficulties in future work.

\section{REFERENCES}

Barthold, Thomas A. (1993). "How Should We Measure Distribution?" National Tax Journal 46 (September):291-300.

_ ogy." In Distributional Analysis of Tax Policy, David F. Bradford (ed.). Washington: American Enterprise Institute.

Bartlett, Bruce (1995). "Replacing Federal Taxes with a Sales Tax." Tax Notes (August 21):997-1003.

Bradford, David F. (1995). "Introduction." In Distributional Analysis of Tax Policy, David F. Bradford (ed.). Washington: American Enterprise Institute.

(1996). "Consumption Taxes: Some Fundamental Transition Issues." In Frontiers of Tax Reform, Michael J. Boskin (ed.). Stanford: Hoover Institution Press.

Branch, E. Raphael (1994). "The Consumer Expenditure Survey: A Comparative Analysis." Monthly Labor Review 117 (December):47-55.

Bull, Nicholas, and Lawrence B. Lindsey (1996). "Monetary Implications of Tax

Reforms." National Tax Journal 49 (September):359-379. 
Burton, David R., and Dan R. Mastromarco (1996). "The National Sales Tax: Moving Beyond the Idea." Tax Notes (May 27):1237-1247.

Caspersen, Erik, and Gilbert E. Metcalf (1994). "Is the Value Added Tax Regressive? Annual Versus Lifetime Incidence Measures." National Tax Journal 47: 731-746.

Davies, James, France St. Hilaire, and John Whalley (1984). "Some Calculations of Lifetime Tax Incidence." American Economic Review 74 (September): 633-649.

Feldstein, Martin (1988). "Imputing Corporate Tax Liabilities to Individual Taxpayers." National Tax Journal 41(1):37-60.

Fullerton, Don, and Diane Lim Rodgers (1993). Who Bears the Lifetime Tax Burden? Washington, DC: The Brookings Institution.

Gale, William G., Scott Houser, and John Karl Scholz (1996). "Distributional Effects of Fundamental Tax Reform." In Fundamental Tax Reform, Henry Aaron and William Gale (eds.). Washington, DC: The Brookings Institution.

Gentry, William, and R. Glenn Hubbard (1997). "Distributional Implications of Introducing a Broad-Based Consumption Tax." In Tax Policy and the Economy, vol. 11, James M. Poterba (ed.). Cambridge: MIT Press.

Gieseman, Raymond (1987). "The Consumer Expenditure Survey: Quality Control by Comparative Analysis." Monthly Labor Review 110 (March):8-13.

Graetz, Michael (1980). "Expenditure Tax Design." In Which Should Be Taxed: Income or Expenditure? Joseph A. Pechman (ed.). Washington, DC: The Brookings Institution.

Hall, Robert E. (1996). "The Effects of Tax Reform on Prices and Asset Values." In Tax Policy and the Economy, vol. 10, James M. Poterba (ed.). Cambridge, MA: MIT Press.

Harberger, Arnold (1962). "The Incidence of the Corporation Income Tax." Journal of Political Economy 70:215-240.

Kasten, Richard J., and Eric Toder (1995). "Distributional Analysis at the Congressional Budget Office." In Distributional Analysis of Tax Policy, David F. Bradford (ed.). Washington: American Enterprise Institute.

Kotlikoff, Laurence J. (1993). "The Economic Impact of Replacing Federal Income Taxes with a Sales Tax." Cato Institute Policy Analysis no. 193. Washington, DC: Cato Institute.

Mankiw, N. Gregory, and Lawrence H. Summers (1986). "Money Demand and the Effects of Fiscal Policies." Journal of Money Credit and Banking 18 (November):415-429.

Metcalf, Gilbert E. (1994). "Life Cycle Versus Annual Perspectives on the Incidence of a Value Added Tax." In Tax Policy and the Economy, vol. 8, James M. Poterba (ed.). Cambridge, MA: MTT Press.

Nunns, James R. (1995). "Distributional Analysis at the Office of Tax Analysis." In Distributional Analysis of Tax Policy, David F. Bradford (ed.). Washington: American Enterprise Institute.

Okner, Benjamin A. (1974). "Data Matching and Merging: An Overview." Annals of Economic and Social Measurement 3:347-352.

Park, Thae S. (1994). "Federal Personal Income Tax Liabilities and Payments: Revised and Updated Estimates 1991-1993." Survey of Current Business 74 (September):55-57.

Pechman, Joseph (1985). Who Paid the Taxes, 1966-85? Washington, DC: The Brookings Institution. 
Poterba, James M. (1989). "Lifetime Incidence and the Distributional Burden of Excise Taxes." American Economic Review 79 (May):325-330.

, Julio J. Rotemberg, and Lawrence H. Summers (1986). "A Tax-Based Test of Nominal Rigidities." American Economic Review 76 (September):659-675.

Sabelhaus, John (1996). "Consumer Expenditure Survey: Family-Level Extracts, 1980:1-1994:1." Congressional Budget Office, Washington, DC. Mimeograph.

Slemrod, Joel B. (1992). "Taxation and Inequality: A Time-Exposure Perspective." In Tax Policy and the Economy, vol. 6, James M. Poterba (ed.). Cambridge: MIT Press.

U.S. Bureau of the Census (1992). Measuring the Effect of Benefits and Taxes on Income and Poverty: 1991. Current Population Reports, series P60-186. Washington, DC: U.S. Government Printing Office.

U.S. Congress, Joint Committee on Taxation (1993). Methodology and Issues in Measuring Changes in the Distribution of Tax Burdens. Washington, DC: U.S. Government Printing Office.

U.S. Department of Labor (1995). Consumer Expenditure Survey, 1992-93 Bureau of Labor Statistics Bulletin no. 2462. Washington, DC: U.S. Government Printing Office.

U.S. Department of the Treasury (1984). Tax Reform for Fairness, Simplicity, and Economic Growth. Washington, DC: U.S. Government Printing Office. 
